\title{
A COMPARATIVE STUDY OF THE CONJUCTIVAL BACTERIAL NORMAL FLORA IN PAEDIATRIC AND GERIATRIC SUBJECTS
}

\author{
BY \\ *AMAECHI, O. U. AND INYANGA, P. C. \\ DEPARTMENT OF OPTOMETRY, ABIA STATE UNIVERSITY \\ UTURU, ABIA STATE, NIGERIA \\ Email:okamaechi@yahoo.com \\ *Corresponding author
}

\section{ABSTRACT}

The conjunctival bacterial normal flora of twenty healthy paediatric and twenty healthy geriatric subjects were studied. Conjunctival swabs were collected from paediatric subjects aged 2 months to $6 y e a r s$, and geriatric subjects aged 60years and above. The specimens were inoculated unto blood agar and incubated for 24-48 hour as the case may be. They were subsequently subjected to physical examinations using +20.00D magnifying lens; and biochemical tests using gram staining and coagulase test. Thirteen (32.5\%) of the 40 samples yielded growth (3 paediatric and 10 geriatiric samples). The total number of colonies was 37 in paediatric and 217 in geariatric samples. Staphylococcus epidermidis was the most predominant bacterial organism. The $\mathrm{X}^{2}$ test showed significant $(\mathrm{P}<0.05)$ difference in the bacterial normal flora of paediatric and geriatric samples, both in presence of isolates and the number of colonies. The absence of growth in majority of the samples is because of the sterile nature of the normal conjunctiva. The effect of age on the conjunctival bacterial normal flora is further highlighted.

KEYWORDS: Bacterial normal flora, Conjunctiva, Paediatric subjects, Geriatric subjects, Staphylococcus.

\section{INTRODUCTION}

The internal organs of the normal human blood like body, brain among others with exception of the gastrointestinal tract are normally free of microorganism. However, the surfaces of the body which are in contact with the environment like the skin and mucous membranes rapidly become colonized by organisms present in the environment ${ }^{1}$.

The conjunctiva as a mucus membrane sustains permanent flora of indigenous bacteria. A variety of organisms may be cultivated from the normal conjunctiva, but the number of organisms is usually small. The conjunctiva is kept moist and healthy by the continuous secretions from the lacrimal glands. Blinking wipes the conjunctiva every few seconds, mechanically washing away foreign matters including bacteria. Tears also contain bactericidal substances including lysozyme. The primary microbial organisms retrieved from normal uninfected conjunctiva are staphylococcus epidermidis, and certain corynebacterium species, staphylococcus auerus, some streptococci; Haemophilus species and Neisseria species are occasionally found $2^{3}$. The range of these microorganisms, however, varies in different individuals due to variations in genetic make-up, age, nutrition, race and sex ${ }^{2,4}$.

This highlights the objective of this study, which is the effect of age on the conjunctival normal flora. It is important to note here that these indigenous bacteria may become opportunistic, that is, become pathogenic, if suitable opportunity arise. The establishment, therefore, of the indigenous bacteria in these major age groups would guide the eye care practitioner in appropriate drug prescription.

\section{MATERIALS AND METHODS}

The study populations were 20 healthy paediatric subjects aged 2month to 6 years, and 20 healthy geriatric subjects aged 60years and above. These subjects were adjudged healthy (free of systemic and ocular disorders and drug intake two weeks prior to study) after carrying out some preliminary test.

Conjunctival swabs were collected from the lower palpebral conjunctiva of the right eye of the subjects. The samples were taken to the laboratory for culturing and identification. The culture medium used was blood agar. The specimens from the swab sticks were used to make a smear on the culture plates (primary inoculum) and incubated aerobically at $37^{\circ} \mathrm{C}$ for 24 hours. A secondary 
inoculum of cultures that had no growth within 24hours was made and re-incubated for another 24hours.

The growths on the culture plates were identified after 24-48 hours using physical examinations (morphological characteristics and colony count with the help of a +20.00D magnifying lens), and biochemical tests (Gram staining and coagulase test) according to Baker et $\mathrm{al}^{5}$.

The chi-square $\left(\mathrm{X}^{2}\right)$ test at the 0.05 level of significance was used to test for statistical independence of the 2 group of enumerative data (counts and frequencies).

\section{RESULTS}

The presence of isolates and the quantity (number of colonies) of isolates are shown in tables 1 and 2 respectively.

Out of the 40 samples, 13 cultures yielded growth (3 paediatric samples and 10 geriatric samples) as shown in table 1 . The total number was of colonies 37 in the paediatric samples and 217 in the geriatric samples (table 2).

The data when subjected to statistical analysis using $\mathrm{X}^{2}$ test at the 0.05 level of significance showed significant difference in the conjunctival bacterial normal flora of the paediatric and geriatric samples both in the presence of isolates and number of colonies $\left(\mathrm{X}_{\text {cal9.27 }}^{2}>\mathrm{X}_{\text {tab7.82 }}^{2}\right.$ and $\mathrm{X}_{\text {cal } 49.45}^{2}$ $>\mathrm{X}_{\text {tab7.82 }}^{2}$ respectively).

\section{DISCUSSION}

Thirteen $(32.5 \%)$ of the 40 samples cultured yielded growth, 3(7.50\%) were paediatric and $10(25.00 \%)$ were geriatric. The absence of growth in majority of the cultured samples $(67.5 \%)$ has also been documented by other authors ${ }^{2,3,6,7,8,9,10}$. This is because the conjunctival sac is either sterile or normally contains small numbers of aerobic, anaerobic, or facultative bacteria; which also explains the small quantities of isolates found even where growth was recorded.

The bacterial organisms isolated in order of dominance were staphylococcus epidermidis, staphylococcus aureus, Bacillus spp, and actinomycetes spp. Each sample yielded one type of microorganisms, in other words no two types of microorganisms were found on one sample. A similar study carried out by McNatt et $\mathrm{al}^{10}$, also isolated one type of microorganism from each of the samples that yielded growth. This is explained by the fact that the local defense of the eye continues to be intact thereby preventing the fixation of invading microorganism.

Staphylococcus epidermidis has the highest frequency of occurrence, which is in consonance with studies by other researchers.

A significant difference was observed in the number of species and the number of colonies of each specie of the conjunctival bacterial normal flora in paediatric and geriatric samples. This agrees with what was reported by Singer et $\mathrm{al}^{13}$, that adults showed a greater number and quantity (population) of species per eye than did younger subjects.

Actinomycetes spp, was isolated in the paediatric sample, though in very small quantity this suggests that actinomycetes, which is normally present in the pharynx and mouth, could also be part of the conjunctival normal flora, probably because of children's poor habit of moving their hands from the mouth to the eye.

The geriatrics would be more prone to opportunistic infections of the conjunctiva since they showed more types and quantity of microorganisms in their conjunctiva samples. It is therefore reiterated that geriatric subjects should visit the eye care practitioners more routinely.

TABLE 1: NUMBER (PRESENCE) OF ISOLATES

\begin{tabular}{|l|l|l|l|l|l|}
\hline Sample & $\begin{array}{l}\text { Staph. } \\
\text { aureus }\end{array}$ & $\begin{array}{l}\text { Staph. } \\
\text { epidermidis }\end{array}$ & Bacillus spp. & $\begin{array}{l}\text { Actinomycetes } \\
\text { spp }\end{array}$ & Total \\
\hline $\begin{array}{l}\text { Paediatric } \\
\text { Sample }\end{array}$ & 0 & 0 & 2 & 1 & $3(7.50 \%)$ \\
\hline $\begin{array}{l}\text { Geriatric } \\
\text { Samples }\end{array}$ & 4 & 5 & 1 & 0 & $10(25.00 \%)$ \\
\hline Total & 4 & 5 & 3 & 1 & $13(32.50 \%)$ \\
\hline
\end{tabular}




\section{*AMAECHII, O. U. AND INYANGA, R. C.}

TABLE 2: QUANTITY (NUMBER OF COLONIES) OF ISOLATES

\begin{tabular}{|l|l|l|l|l|l|}
\hline Samples & $\begin{array}{l}\text { Staph } \\
\text { aureus }\end{array}$ & $\begin{array}{l}\text { Staph } \\
\text { epidermidis }\end{array}$ & $\begin{array}{l}\text { Bacillus } \\
\text { spp. }\end{array}$ & Actinomycetes spp & Total \\
\hline $\begin{array}{l}\text { Peadiatric } \\
\text { Samples }\end{array}$ & 0 & 0 & 27 & 10 & 37 \\
\hline $\begin{array}{l}\text { Geriatrics } \\
\text { Samples }\end{array}$ & 96 & 96 & 25 & 0 & 217 \\
\hline Total & 96 & 96 & 52 & 10 & 254 \\
\hline
\end{tabular}

\section{R E F E R E N C E S}

1. Brooks, G. F., Butel, J. S. and Morse, S. A. (2001): Normal microbial flora of the human body in: Melnick and Adelberg's Medical Microbiology. $22^{\text {nd }}$ edn. McGraw Hill, pp1769.

2. Batlet, J. D., and Jaanus, S. D. (2001): Normal flora of the conjunctiva in: Clinical Ocular Pharmacology. $4^{\text {th }}$ edn. ButterworthHeinemann, pp545-94.

3. Fahmy, J. A. (1975): Bacterial flora of the normal conjunctiva. Acta Ophthalmol, 53(2): 235-37.

4. Haessaert, S. P. (1993): Clinical manual of ocular Microbiology and Cytology. St Louis Mosby year Book, 134pp.

5. Baker, F. J. Silverton, R. E., and Pallister, C. J. (1998): Gram staining technique in: Introduction to Medical Laboratory Technology. $7^{\text {th }}$ edn. Butterworth-Heniemann, pp249-325.

6. Hovding, G. (1981): The conjunctival and contact lens bacterial flora during lens wear. Acta Ophthalmol. (Copenh), 59:387-401.

7. Isemberg, S. J., Apt, L., Yoshimori, R., and
Alvarez, S. R. (1986): Bacterial flora of the conjunctiva at Birth. J. Pediat. Ophthalmol. Strab, 23:284-6.

8. Kanski, J. J. (1994): Anatomy of the conjunctiva In: Clinical Ophthalmology: A Systematic Approach. $3^{\text {rd }}$ edn. ButterwortHeinemann, pp72-97.

9. Matsaura, H. (1971): Anaerobes in the bacteria flora of the conjunctival sac. Arch. Jap. J. Ophthalmol, 15)2): 116-24.

10. McNatt, J., Allen, S. D., Wilson, L. A., and Dowell, V. R. Jr. (1976): Anaerobic flora of the normal human conjunctival sac. Arch. Ophthalmol, 96(8): 1448-50.

11. Hartikainen, J., Olli-pekka, L., and Saari Matti, K. (1996): Bacteriology of lacrimal duct obstruction. Fin. J. Ophthalmol, 7:205-20.

12. Pramhus, C., Runyan, T. E., and Lindbery, B. R. (1978): Ocular flora in the severely burned patient. Arch Ophthalmol, 96:1421-4.

13. Singer, T. R., Isenberg, S. J., and Apt L. (1988): Conjunctival anaerobic and aerobic bacterial flora in paediatric versus adult subjects. Br. J. Ophthalmol, 71:448-51. 